\title{
Does Faith Limit Immorality? The Politics of Religion and Corruption
}

Article in Democratization · January 2012

DOI: $10.1080 / 13510347.2011 .650914$

\section{CITATIONS}

11

3 authors, including:

\section{Udi Sommer}

Columbia University

37 PUBLICATIONS 78 CITATIONS

SEE PROFILE
Gizem Arikan

Trinity College Dublin

14 PUBLICATIONS 116 CITATIONS

SEE PROFILE

Some of the authors of this publication are also working on these related projects:

Project Supreme Court Agenda Setting View project

When and why are people interested in exploring foreign cultures or interacting with people from Project foreign cultures? View project 


\title{
Does faith limit immorality? The politics of religion and corruption
}

\author{
Udi Sommer*a $^{*}$, Pazit Ben-Nun Bloom ${ }^{\mathrm{b}}$ and Gizem Arikan ${ }^{\mathrm{c}}$ \\ ${ }^{a}$ Department of Political Science, Tel Aviv University, Tel Aviv, Israel; ${ }^{b}$ Department of \\ Political Science, Hebrew University, Jerusalem, Israel; ${ }^{c}$ Department of International \\ Relations, Yasar University, Izmir, Turkey
}

(Received 1 August 2011; final version received 1 November 2011)

\begin{abstract}
Critically considering scholarship relating religiosity to ethical behaviour, we contend that religion is systematically related to levels of corruption, and that the nature of this relationship is contingent on the presence of democratic institutions. In democracies, where political institutions are designed to inhibit corrupt conduct, the morality provided by religion is related to attenuated corruption. Conversely, in systems lacking democratic institutions, moral behaviour is not tantamount to staying away from corrupt ways. Accordingly, in non-democratic contexts, religion would not be associated with decreased corruption. Time-series cross-sectional analyses of aggregate data for 129 countries for 12 years, as well as individual level analyses of data from the World Values Surveys, strongly corroborate the predictions of our theory. The correlation of religion with reduced corruption is conditional on the extent to which political institutions are democratic.
\end{abstract}

Keywords: democratic institutions; corruption; religious freedom; democracy

Country A prides itself on its democratic form of government, but highly regulates religion. Country B is a non-democracy, but public officials are free to express their faith publicly. Which would you expect to show more government-level corruption? This is an easy question. Decades of democratic theories and corruption studies (as well as the daily news) indicate that on average non-democracies are more corrupt. However, which would you predict to have higher levels of corruption of the following two democracies: Country A, where religion is highly regulated, or Country $\mathrm{C}$, which regulates religion only to a limited extent? The key argument in this article is that a democratic form of government conditions the effects of religion on moral behaviour. Country A-type democracies would experience less corruption than non-democracies. Yet, ceteris paribus, corruption levels in Country A would be higher compared to Country C, due to higher levels of

${ }^{*}$ Corresponding author. Email: udi.sommer@gmail.com 
religion regulation in the former. Hence, with the appropriate institutional platform, religion may be instrumental in the eradication of corruption.

Based on existing studies that show a positive relationship between religion and ethical behaviour, this article first posits that limiting religious elements in the nation's institutions leads to an increase in the prevalence of corrupt behaviour. However, we also contend that the institutional context is crucial. It moderates the effect of religious cues on corruption. In a democratic environment, corruption is viewed as unethical and inappropriate. In such a context, the effect of religion, which is to increase the kind of behaviour that is perceived as ethical, would translate into decreased corruption. In the absence of a democratic infrastructure, behaving morally does not necessarily connote staying away from corrupt ways. Hence, we expect religion to interact with democratic institutions such that in the absence of democratic institutions, the limiting effect of religious freedom on corruption would wane.

Using cross-national time-series data from 129 countries, collected between 1990 and 2002, we show that freedom of religion (measured as the lack of religious regulation and religious discrimination towards minorities) contributes to decreasing corruption, and that this beneficial effect of freedom of religion is contingent on a democratic environment. Further, our argument rests on the assumption that for religious cues to reduce corruption, the public must internalize democratic values and perceive corruption as being destructive to a democratic form of government. To test this individual-level component of our theory, we conduct individual level analyses with data from the fifth wave of the World Values Surveys. The individual-level analyses indicate that holding democratic values boosts the effect of religiousness on attitudes towards corruption.

\section{Explaining corruption}

Corruption is the use of government powers by government officials for illegitimate private gain. ${ }^{1}$ By far the most widely examined antecedent of corruption in the political science literature is institutional design. This is true particularly insofar as those institutions increase competition. ${ }^{2}$ One aspect of institutional design that instigates healthy competition and thus also affects corruption is the clarity with which accountability may be assigned. Through their effects on the clarity of governmental responsibility, political institutions influence the level of corruption. ${ }^{3}$

The types of institutions whose effects on corruption have been examined are varied. The size of the government is one key institutional predictor of corruption. ${ }^{4}$ How accountability is formally enforced ${ }^{5}$ and the electoral rules ${ }^{6}$ also affect corruption. ${ }^{7}$ The constitutional structure may also lead to corruption, with more centralized constitutions (for example, unitary as opposed to federal systems) decreasing the likelihood of corruption ${ }^{8}$ and with district magnitude also having an effect. ${ }^{9}$ Further, legal reforms, ${ }^{10}$ the type of party system, ${ }^{11}$ and the institutional organization of the public sector ${ }^{12}$ influence corruption as well, together with a range of additional economic and institutional variables. ${ }^{13}$ 
On the other hand, some scholars have gone beyond the scholarship that emphasizes the institutional antecedents for corruption. For example, while Uslaner acknowledges the role of poor policy choices in increasing corruption his main emphasis is on the economic or social sources of corruption. ${ }^{14}$ According to Uslaner, inequality works its way through low interpersonal trust to increase corrupt conduct. In addition to social capital and trust, cultural value orientations have also been suggested as important factors underlying corruption. For instance, Hofstede's individualism and Schwartz's autonomy and egalitarianism dimensions were positively related to non-corruption and the rule of law. ${ }^{15}$ Cultural values that legitimize the use of power and the exploitation of others (for example, Hofstede's power distance and Schwartz's hierarchy dimension) have been associated with more corruption. ${ }^{16}$ Conversely, trust has been regarded as a key factor in promoting good governance, as it facilitates collective action, which is key for limiting corruption. $^{17}$

Most pertinent to our investigation, some research has considered the role of specific religious beliefs in promoting or deterring corruption. ${ }^{18}$ Following Weber's perspective on the values and beliefs embedded in Protestant religion, most of these studies have posited that religion could play a role in either reducing or increasing corruption, depending on the values and belief systems dominant in the particular denomination. Protestantism is usually associated with lower levels of corruption because it promotes the values of individualism and is less hierarchical and authoritarian than other religions. ${ }^{19}$ On the other hand, Confucian or Islamic societies are more collectivist and hierarchical ${ }^{20}$ and therefore are associated with more corruption. Putnam ${ }^{21}$ and Landes ${ }^{22}$ have argued that Catholic religion has historically had an adverse effect on good governance, hence increasing corruption because it promotes 'vertical bonds of authority'. ${ }^{23}$ What is more, Catholicism has historically acquired a culture of intolerance and closed-mindedness that has retarded development. ${ }^{24}$ According to Landes, as intolerance is present in Islam as well, Muslim societies tend to be more susceptible to corruption. Finally, some scholars have argued that corruption is the result of social norms and exists in cultures where loyalty to clan trumps loyalty to the state. ${ }^{25}$

In this article, we attempt to go beyond existing arguments concerning the effect of religious values on good governance. First, we seek to emphasize the role of religion in general in affecting corruption, rather than the teachings of specific denominations. This is one key advance upon extant literature - we go beyond religious identity as a basis for determining the influence of religion on corruption. Second, we are interested in the role of religious elements in the state's institutions. We contend that the ability to freely exercise religion by the masses as well as by public employees in state institutions (for example, observing religious practices, engaging in various public religious activities, freedom to display religious symbols) deters corruption, as long as corruption is viewed as an immoral behaviour in the specific political setting. Therefore, crucially important for the theoretical framework developed below is the interaction between institutions and religion; the effect of religious worldviews on corruption is contingent on the institutional 
platform in place. Whether the polity is a consolidated democracy would influence the extent to which the use of government powers for private gain is legitimate. Consequently, only in a democratic environment would religious elements in the political institutions reduce corruption. In a departure to some of the literature cited above, we contend that, regardless of its specific beliefs and teachings, any religion has the potential to promote ethical and moral behaviour. For this to happen, though, the state must provide an environment in which religious views can be expressed and practiced freely and the political system should be democratic.

\section{Religion and moral behaviour}

Religion provides a language of ethics, as it serves as a constant reminder of what is considered good and evil. As such, religion may be translated into political virtuousness and integrity. Indeed, studies show that individual level religiosity is usually connected to ethical political behaviour. For example, an analysis of data from more than 30 countries shows higher levels of tax morale among religious participants. ${ }^{26}$ Along the same lines, there is also a vast literature connecting religiosity to philanthropy and charity. ${ }^{27}$

An emerging body of experimental literature suggests that moral conduct is promoted in an environment with religious elements. In fact, current studies argue and demonstrate that subtle and even subliminal religious cues in the environment can boost ethical behaviour among both the devout and the secular. Mazar, Amir, and Ariely argue that religious cues increase attention to moral standards, notwithstanding how devout one is. ${ }^{28}$ The amplified attention to one's moral compass, in turn, increases the tendency to act in accordance with these moral standards.

Presenting participants with religious concepts promotes moral behaviour, ${ }^{29}$ the punishment of unfair behaviour, ${ }^{30}$ and pro-social behaviour. ${ }^{31}$ What is more, religious cues were found to increase one's ethical standards; a recent experimental study shows that mere exposure to religious concepts significantly decreases the likelihood of cheating in a difficult $\operatorname{task}^{32}$ and increases ethical behaviour more generally. ${ }^{33}$ To explain why exposure to religious content increases ethical behaviour, some argue that religious cues increase the accessibility of thoughts about a supernatural watcher ${ }^{34}$ or about the moral behaviour of religious figures. ${ }^{35}$

Applying these findings to the realm of politics, religious cues in the political environment may boost the standards of honesty among decision-makers. The morally purifying effect of religion in Mazar, Amir, and Ariely is not contingent on a person's religiosity ${ }^{36}$; simply knowing that the Ten Commandments are about moral rules proved to be sufficient to increase attention to moral standards in individuals. This, in turn, increased the likelihood of behaviour consistent with these standards. In sum, it is not just the religiosity of decision-makers that affects their moral behaviour. Rather, it is the presence of religious cues in the institutional environment in which they operate that would have this effect. We first argue, therefore, that the presence of religious cues in state institutions will work to 
increase moral behaviour on the part of decision-makers. Therefore, corruption should decline with the salience and presence of religion in state institutions. Conversely, restrictions on the freedom to express religious beliefs or practice religion may hinder the positive effect of religiosity on reducing corrupt behaviour. Therefore, regulation of religion by the state is expected to be associated with higher levels of corruption:

H1: Higher levels of religious regulation should be associated with increased corruption.

While religious priming has a robust effect on pro-social behaviour in some contexts, religion has a darker side too. The political science literature has long documented religion as connected to prejudice and political intolerance. ${ }^{37}$ While most of these works are concerned with the effect of individual religious beliefs, the effect of religion-state relationship on religious tolerance, religious freedom, and human rights records is also revealed in some aggregated cross-national analyses. For instance, state regulation of religious activity ${ }^{38}$ as well as legislation of religion into law and state support for one or more religions ${ }^{39}$ are found to increase discrimination against minority religions and worsen a state's level of human rights practice.

Similarly, experimental work indicates that religion may activate anti-social behaviour towards out-groups ${ }^{40}$ and increase support for suicide attacks against the out-group. ${ }^{41}$ Thus, for religion to be associated with reduced corruption, it should increase self-transcendence (rather than in-group favouritism and out-group resentment). For that matter, the political environment should not only provide freedom to express religious worldviews, engage in religious activities, and display religious symbols, but also allow for religious pluralism. When the state discriminates against certain religious groups, we do not expect religion to motivate ethical behaviour. Therefore, religious discrimination is expected to be correlated with increased levels of corruption in a country:

$\mathrm{H} 2$ : Higher levels of religious discrimination should be associated with increased corruption.

\section{Religion and corruption: the moderating role of democracy}

While we hypothesize that religious cues in general have the potential to reduce corruption by increasing accessibility to one's moral standards, we also posit that the effect of religion on corruption is dependent on the institutional environment within which the individual is located. For religious cues to reduce corruption, public servants have to see their ethics as relevant to their work. Increased attention to one's moral compass brought about by religious cues should reduce corruption only to the extent that such behaviour is perceived by the individual as normatively wrong. This would be a function of how democratic one's context is. $^{42}$ 
One of our key arguments is that democratic institutions have an indirect effect on reducing corrupt behaviour via their effect on the relationship between religion and corruption. In a democratic system, corruption is perceived as an immoral act. In consolidated democracies where checks and balances function, elements crucial for deterring corruption such as an independent judiciary, a political culture, and free media that stress integrity are all in place. In addition, public opinion is prone to concern with post-materialistic needs of self-actualization, quality of life, and self-expression, which underlie anti-corruption pressures. ${ }^{43}$ Put together, these characteristics of democracies make clear that the use of government powers for private gain is unethical and normatively wrong. Thus, in such an environment, activation of moral standards through religious cues is expected to reduce the likelihood of corruption. Conversely, in an institutional context where corruption is not viewed as morally wrong, religious cues that activate one's moral compass are not expected to decrease corruption. In a political environment where corruption is not viewed as categorically wrong, religious cues cannot be expected to hold it back.

H3: Democratic governance moderates the relationship between religious freedom and corruption such that higher levels of democracy are expected to strengthen the effect of religion on reduced corruption, while lower levels of democracy would attenuate the effect of religion on corruption.

Apart from the interactive effect, it is generally expected that democratic conditions depress corruption. First, knowing that their conduct is subject to scrutiny constrains officials to loyally carry out their duty. ${ }^{44}$ A democratic form of government increases the likelihood of institutionalized penalty, which in turn shapes the cost-benefit analysis of elites. In addition to its effects via political institutions, democracy also moulds the political culture and the prevailing values, affecting both the public's tolerance for corruption and the elite's belief system.

H4: Democracies will show lower levels of corruption.

Finally, we control for variables traditionally associated with corruption. These include history as a British colony, ${ }^{45}$ gross domestic product (GDP), openness to trade, and globalization. We also control for the size of different religious groups in the nation.

\section{Data and methods}

We test our core hypotheses concerning the effect of religious freedoms on corruption using cross-sectional time-series data collected between 1990 and 2002. The time period under study is dictated more by the data than theoretical constraints. While data on other variables are widely available from many sources, timeseries data for religious freedom measures (such as religious regulation and discrimination towards minorities) is compiled by Religion and the State (RAS) Project and is currently only available for the period between 1990 and 2002. 
Data for the dependent variable, Level of Corruption, are taken from International Country Risk Guide's Political Risk Ratings. The scale is 0 to 1, with values closer to 1 indicating a political system with higher levels of corruption. The Political Risk Ratings are taken from the Political Risk Services (PRS) data available for purchase from the PRS group, a research group focused on political risk analysis, whose ratings are used extensively in academic work. ${ }^{46}$ This type of data is the most appropriate for the time-series aspect of the empirical tests conducted here. As Thompson and Shah suggest, those indicators suggesting limited variance over time (for example, Transparency International's index) are not adequate to gauge temporal change because of the measurement strategy used to compile them. ${ }^{47}$

Data for the predictors are taken from several sources. Data on state activity in the area of religion come from the Religion and State (RAS) project as mentioned above. This is a university-based project that includes a set of measures used to systematically gauge the intersection between government and religion. Three independent variables are used based on the RAS data. ${ }^{48}$ Religious Regulation is the first of these and addresses whether the state regulates either all religions or the majority religion. The measure combines specific types of religious restrictions that a government may place on the majority religion, or on all religions, including but not limited to restrictions on religious political parties, formal religious organizations, restrictions on public observance of religious practices, and public religious speech. Religious Discrimination against Minorities is the second outcome variable that measures the extent of religious freedom, and ranges from 0 (no restrictions on minorities) to 48 (minorities are prohibited or sharply restricted from public observance of religious services, building and maintaining places of worship, are forced to observe religious laws of other groups, their religious organizations are restricted, religious education restricted, there is arrest or harassment of religious figures, restrictions on the ability to make materials necessary for religious rites, restrictions on ability to write, disseminate, or publish religious material, restrictions on observance of religious laws concerning personal status, forced conversions, restrictions on proselytizing, and requirement for the minority religions to register in order to be legal or receive special tax status). ${ }^{49}$ To facilitate interpretation by allowing a comparison of effect sizes, both variables are recoded to vary between 0 and 1 . Higher values were coded to indicate higher levels of regulation and discrimination.

To measure Democratic Conditions, we utilize the Freedom House/Polity measure, which transforms the average of Freedom House and Polity scales to one that varies between 0 (least democratic) and 10 (most democratic) and imputes the values where data on Polity is missing by regressing Polity on the average. ${ }^{50}$ In addition, we control for variables traditionally associated with corruption. Globalization Scale is the weighted average of three variables: social globalization, economic globalization, and political globalization. ${ }^{51}$ The Social Globalization measure includes three categories of indicators: personal contacts (for example, telephone traffic and tourism), information flows (for example, 
number of internet users), and cultural proximity (for example, trade books and number of IKEA warehouses per capita). Economic Globalization is measured by restrictions on trade and capital such as tariff rates, and by actual flows of trade and investments. The index of Political Globalization is measured by the number of embassies and high commissions in a country, the number of memberships the country has in international organizations, participation in UN peacekeeping missions, and the number of international treaties signed since 1945. Predictors for Percent From Religious Denomination reflect the share of each of those denominations in the population (RAS dataset). GDP per capita in constant US dollars at base year 2000 was used as a proxy for levels of modernization. Missing data were imputed using the CIA World Fact Book. ${ }^{52}$ Postcommunism is a dummy variable coded 1 if the country has a communist legacy.

We use time-series cross-sectional data, listing all states in the abovementioned datasets for which data were available for the period 1990-2002. We employ a generalized estimating equation (GEE) model. ${ }^{53}$ A marginal approach, such as the GEE, is appropriate in this case since we are interested in the variables that influence corruption. ${ }^{54}$ We employ a GEE model with first-order autoregressive component. We use robust standard errors clustered on the nation.

\section{Results}

What is the relation between religion and corruption? Table 1 presents the results of the cross-national time-series portion of the analysis. Model I examines the effects of religious regulation and religious discrimination against minorities, controlling for the effects of other independent variables. In Model II we add controls for the dominance of a range of religious denominations in the nation. The results of these models provide strong empirical support for Hypotheses 1 to 4 .

Model I lends support to both $\mathrm{H} 1$ and $\mathrm{H} 2$. We find that as freedom of religion increases (that is, as religious regulation and discrimination against minorities decrease), corruption declines. Thus, all else being equal, nations that regulate religion more tend to have higher levels of corruption. In addition, religious discrimination also boosts corruption. In countries where the rights and freedoms of minority religions are not respected, corrupt behaviour tends to increase. Next, we find evidence that more democratic states are less corrupt than less democratic nations on average, which lends support to H4. In addition, control variables show that economic development measured as GDP per capita has the effect of deterring corruption, and that former British colonies suffer from corruption to a greater extent than countries not formerly under British rule. While this result is contrary to theoretical claims that link the tradition of British civil service to lower levels of corruption, ${ }^{55}$ at the same time, it is in line with some recent evidence that does not find a significant effect of British colonial heritage on levels of corruption. ${ }^{56}$

Model I provides strong empirical support for the argument that the fewer the religious cues within state institutions - captured as an increased regulation of the religious activities of majority and minority religions as well as attempts to prevent 
Table 1. The effect of state-level religion on corruption.

\begin{tabular}{lcc}
\hline & Model I & Model II \\
\hline Religious regulation & $0.223(0.099)^{* *}$ & $0.196(0.101)^{* *}$ \\
Religious discrimination & $0.271(0.078)^{* * *}$ & $0.256(0.072)^{* * *}$ \\
Democratic conditions & $-0.366(0.200)^{*}$ & $-0.358(0.211)^{*}$ \\
GDP in real \$s - logged & $-0.065(0.012)^{* * *}$ & $-0.062(0.013)^{* * *}$ \\
British colony & $0.048(0.027)^{*}$ & $0.081(0.032)^{* *}$ \\
Post communism & $0.040(0.029)$ & $0.009(0.033)$ \\
Globalization & $-0.023(0.073)$ & $-0.024(0.077)$ \\
\% Catholics & - & $0.001(0.000)$ \\
\% Orthodox & - & $0.000(0.001)$ \\
\% Protestant & - & $-0.002(0.001)^{* * *}$ \\
\% Muslim & - & $-0.000(0.000)$ \\
\% Buddhist & - & $-0.001(0.001)$ \\
\% Hindu & - & $0.008(0.004)^{* *}$ \\
\% Jewish & - & $-0.024(0.054)$ \\
\% Confucians & - & $-0.014(0.006)^{* *}$ \\
$\%$ Sikhs & - & $-0.007(0.013)$ \\
\% Bahais & - & $-0.061(0.054)$ \\
Constant & $1.028^{* * *}(0.091)$ & $1.026(0.092)^{* * *}$ \\
$\mathrm{~N}$ & 1566 & 1566 \\
$\mathrm{~N}$ of groups & 129 & 129 \\
Observations per group & Min 4; Average $12.1 ;$ & Min $4 ;$ Average $12.1 ;$ \\
Wald $\chi^{2}$ & Max 13 & Max 13 \\
& $\chi^{2}(7)=114.82$ & $\chi^{2}(17)=382.67$ \\
\hline & Prob $>\chi^{2}=0.000$ & Prob $>\chi^{2}=0.000$ \\
\hline
\end{tabular}

Notes: Table entries are unstandardized coefficients with standard errors in parentheses. ${ }^{*} P<0.10$, ${ }^{* *} P<0.05,{ }^{* * *} P<0.01$.

minority religions from freely exercising their religions - the stronger the deterring effect on moral behaviour, thus increasing corruption.

In Model II, we also control for the percentage of adherents to major religious traditions. The key results in Model I still hold when controlling for the effect of religious denominations, thus showing that the findings are robust to model specification and the addition of further control variables. We also find that, in general, levels of corruption are not necessarily affected by the presence of the adherents of specific religious traditions. The coefficients for percent of religious adherents are usually not statistically significant with the exception of Protestants and Hindus. The results show that as the percentage of Protestants in a nation increases, corruption is likely to decrease. This result is in line with historical debates and previous empirical evidence concerning the effect of Protestant values on deterring corruption. On the other hand, we do not find support for the argument that Islam or Catholicism are related to more corruption because such religions promote hierarchy and collectivist values that may have the effect of encouraging corrupt behaviour. In sum, religious traditions in a country do not have consistent effects on levels of corruption. 
In order to test our argument concerning the moderating role of levels of democracy on religious freedom and corruption (H3), we added two interaction terms to Model II: level of democracy $\mathrm{x}$ religious regulation and level of democracy $\mathrm{x}$ religious discrimination towards minorities, of them only the former returned statistical significance, and it is depicted in Figure 1. The predicted level of corruption is calculated given changing levels of democratic conditions for religious freedom. The thick gray line in the panel represents established democracies, the darker gray line represents the conditions in developing democracies and the narrow black line indicates the effect of religious freedom in non-democracies. The coefficients of each of the lines and their corresponding confidence intervals are presented in Appendix Table A1.

As Figure 1 indicates, freedom of religion has a negative effect on corruption in democratic countries: as regulation increases, all else being equal, corruption is bound to increase. However, this effect is reversed in non-democracies, where freedom of religion slightly increases corruption. This result confirms our hypothesis that the effect of religious freedom on decreasing corruption is conditional on being a consolidated democracy.

We also test whether economic development and modernization, which are associated with democratization, likewise condition the effect of religious freedom on decreasing corruption. To this end, we again rerun Model II, this time adding the interaction of two religious freedom variables with GDP per capita (as proxies for development and modernization). Figure 2 shows the statistically significant interaction terms. On the $x$-axis in each of the panels is religion, with 1

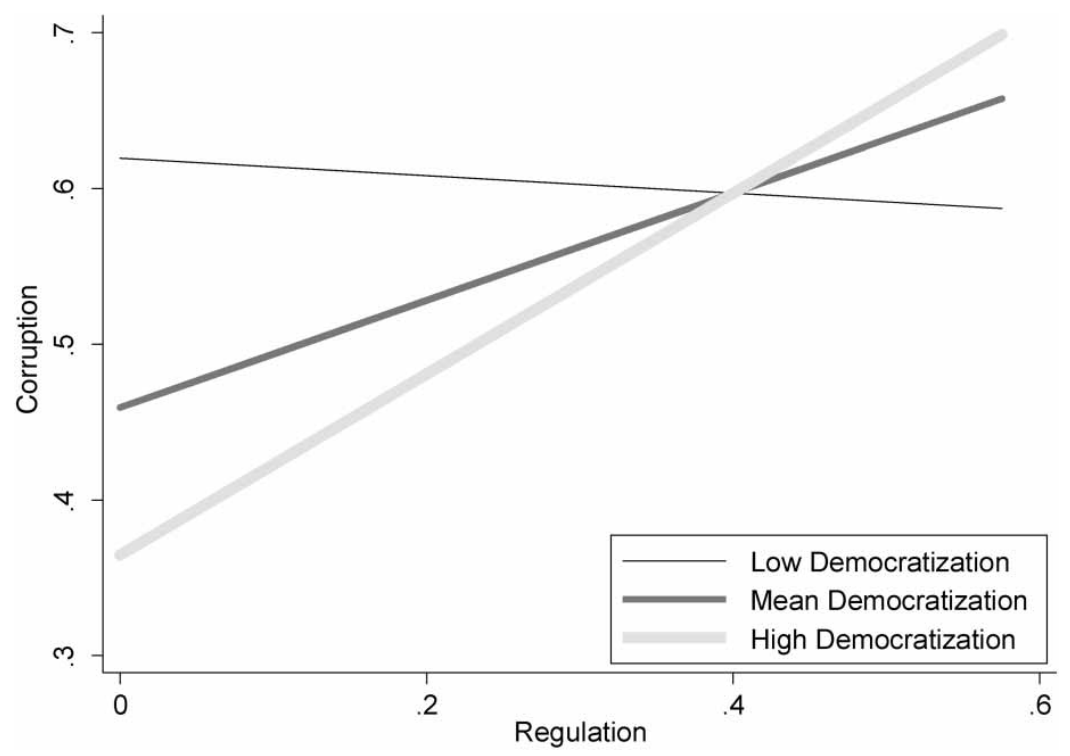

Figure 1. The interactive effect of religiosity and democratization on corruption 

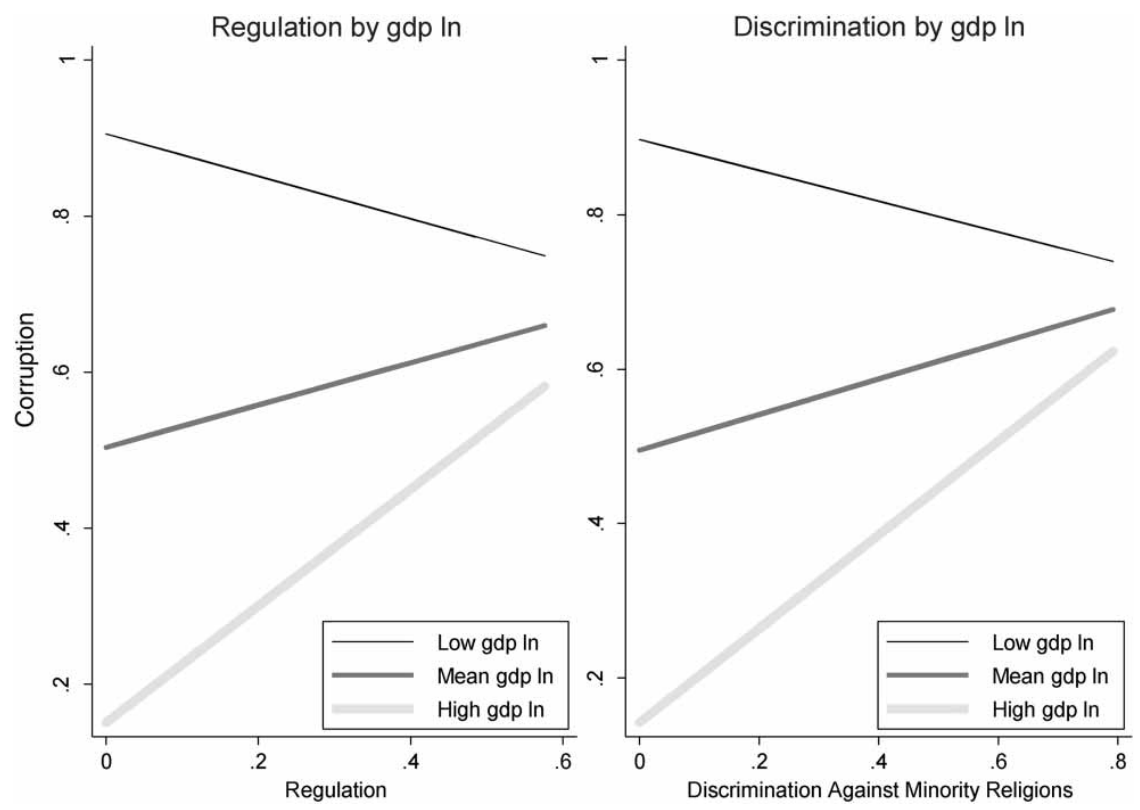

Figure 2. The interactive effect of religiosity and GDP (logged) on corruption

being no freedom of religion (highest regulation, highest discrimination). Regulation is at the left-hand panel, and discrimination to its right. The thick gray line in each panel represents the most affluent countries, the darker gray line represents the mean GDP and the narrow black line indicates the effect of religion in poor countries. The coefficients of each of the lines and their corresponding confidence intervals are presented in Appendix Table A1.

As hypothesized, freedom of religion has a negative effect on corruption in affluent countries; as regulation and discrimination increase, there will be more corruption. However, as Figure 1 indicates, this effect is reversed in poor countries, where freedom of religion does not affect, or even increases, corruption.

Therefore, both Figure 1 and Figure 2 lend strong support to H3. Since our conditional hypothesis assumes that the positive effect of religious freedoms on corruption rests on a public that internalizes democratic values, we also provide below some supporting evidence using analysis of individual-level data.

\section{Supporting analysis: individual-level models}

For religious cues to reduce corruption, the public has to consider religion as tied to ethical behaviour and good governance. We contend that, in a democratic country, corruption is perceived as an immoral act. But this should be relevant only to the extent that a person internalizes the democratic values. As a person internalizes democratic values, $\mathrm{s} / \mathrm{he}$ is more likely to view corruption as a 
threat to democracy. Therefore, we expect democratic values to condition the effect of religious cues on how corrupt behaviour is perceived. We therefore hypothesize that the effect of religiosity on corrupt behaviour is contingent on whether the individual supports a democratic form of government or not. To directly test the mechanism through which religiosity and corruption may be related at the individual level, we use data from the latest wave of the World Values Surveys, which were conducted in 57 countries during 2005. Due to missing items, some countries were not included in the analysis. As a result, the final analysis includes observations from 36 countries. Random intercept multilevel modelling is used to account for the hierarchical nature of the data. ${ }^{57}$

The dependent variable is an additive scale of four variables on the justifiability of the following actions: 'Claiming government benefits to which you are not entitled', 'Avoiding a fare on public transportation', 'Cheating on taxes if you have a chance', and 'Someone accepting a bribe in the course of their duties'. The items are measured as a Likert scale from 1 (never justifiable) to 10 (always justifiable). The scale reliability coefficient of the items, measured by Cronbach's alpha is 0.79 . The final measure is coded to vary between 0 to 1 , where higher values indicate a tendency to justify corrupt behaviour.

As for the predictors, religiosity is measured using three variables. The first variable is a self-assessed religiosity variable. This is a dummy variable coded 1 if the respondent considers herself a religious person, and 0 otherwise. Although far from being ideal, we still include this variable in our analysis. The second is the importance of God in the respondent's life, measured on a Likert scale from 1 (not important) to 10 (very important). Finally, we also include the frequency of church attendance. These variables are recoded to vary between 0 and 1 . We also control for respondents' religious denomination. ${ }^{58}$ Finally, we control for age, level of education, income, gender, ideological orientation, national pride, trust, satisfaction with household income, and confidence in institutions. All these variables, with the exception of age, are normalized to vary between 0 and 1 .

The results in Table 2 largely support the hypotheses that while both religiosity and democratic attitudes are crucial to the justifiability of corruption, support for democratic institutions bolsters the positive effect of religiosity on deterring corrupt behaviour. In Model I, we find that both the importance of God in a respondent's life and attendance at religious services decrease the justifiability of corruption. Support for democracy is significantly and negatively related to justification of corrupt behaviour. Indeed, support for democracy has the strongest effect on support for corrupt behaviour. Model II in Table 2 considers the interaction of self-assessed religiosity and support for democracy on justifiability of corruption. Although the coefficient of religiosity in this model is positive, the interaction effect is negative and statistically significant, indicating that, all else being equal, for a religious person, the marginal effect of supporting democracy on justifiability of corruption is -0.121 . Similar results emerge when we consider the interactive effects of the importance of God and frequency of attendance at religious services. In both Models III and IV, the coefficients of importance of God 
Table 2. Religiosity, democratic attitudes, and justifiability of corruption: individual-level supporting analysis.

\begin{tabular}{|c|c|c|c|c|}
\hline & Model I & Model II & Model III & Model IV \\
\hline \multicolumn{5}{|l|}{ Within-level effects } \\
\hline Religious person & $-0.001(0.003)$ & $0.013(0.008)^{*}$ & $-0.001(0.003)$ & $-0.001(0.003)$ \\
\hline Importance of God & $-0.021(0.005)^{* * *}$ & $-0.020(0.005)^{* * *}$ & $0.000(0.011)$ & $-0.020(0.005)^{* * *}$ \\
\hline Religious attendance & $-0.014(0.004)^{* *}$ & $-0.014(0.004)^{* *}$ & $-0.014(0.004)^{* *}$ & $0.008(0.010)$ \\
\hline Endorsing democracy & $-0.127(0.005)^{* * *}$ & $-0.113(0.009)^{* * *}$ & $-0.107(0.011)^{* * *}$ & $-0.113(0.008)^{* * *}$ \\
\hline Religious x Endorse dem. & - & $-0.021(0.010)^{* *}$ & - & - \\
\hline Imp. God x Endorse dem. & - & - & $-0.028(0.014)^{* *}$ & - \\
\hline Rel. attendance $\mathrm{x}$ Endorse dem. & - & - & - & $-0.031(0.013)^{* *}$ \\
\hline Buddhist & $0.008(0.007)$ & $0.008(0.007)$ & $0.008(0.007)$ & $0.008(0.007)$ \\
\hline Catholic & $0.010(0.004)^{* *}$ & $0.010(0.004)^{* *}$ & $0.010(0.004)^{* *}$ & $0.010(0.004)^{* *}$ \\
\hline Hindu & $0.003(0.012)$ & $0.003(0.012)$ & $0.003(0.012)$ & $0.003(0.012)$ \\
\hline Independent/other & $-0.003(0.006)$ & $-0.003(0.006)$ & $-0.003(0.006)$ & $-0.003(0.006)$ \\
\hline Jewish & $0.035(0.023)$ & $0.035(0.023)$ & $0.035(0.023)$ & $0.035(0.023)$ \\
\hline Muslim & $-0.007(0.008)$ & $-0.007(0.008)$ & $-0.007(0.008)$ & $-0.007(0.008)$ \\
\hline Orthodox & $0.030(0.008)^{* * *}$ & $0.030(0.008)^{* * *}$ & $0.030(0.008)^{* * *}$ & $0.030(0.008)^{* * *}$ \\
\hline Protestant & $-0.006(0.004)$ & $-0.005(0.004)$ & $-0.005(0.004)$ & $-0.005(0.004)$ \\
\hline Evangelical & $0.003(0.006)$ & $0.003(0.006)$ & $0.003(0.006)$ & $0.003(0.006)$ \\
\hline National pride & $-0.056(0.005)^{* * *}$ & $-0.056(0.005)^{* * *}$ & $-0.056(0.005)^{* * *}$ & $-0.056(0.005)^{* * *}$ \\
\hline Trust & $0.007(0.003)^{* *}$ & $0.007(0.003)^{* *}$ & $0.007(0.003)^{* *}$ & $0.007(0.003)^{* *}$ \\
\hline Confidence in institutions & $0.009(0.006)$ & $0.009(0.006)$ & $0.009(0.006)$ & $0.009(0.006)$ \\
\hline Satisfaction with financial situation & $-0.016(0.005)^{* *}$ & $-0.016(0.005) * *$ & $-0.016(0.005)^{* *}$ & $-0.016(0.005)^{* *}$ \\
\hline Ideology & $0.018(0.005)^{* * *}$ & $0.018(0.005)^{* * *}$ & $0.018(0.005)^{* * *}$ & $0.018(0.005)^{* * *}$ \\
\hline Age & $-0.002(0.000)^{* * *}$ & $-0.002(0.000)^{* * *}$ & $-0.002(0.000)^{* * *}$ & $-0.002(0.000)^{* * *}$ \\
\hline Low education & $0.028(0.003)^{* * *}$ & $0.028(0.003)^{* * *}$ & $0.028(0.003)^{* * *}$ & $0.028(0.003)^{* * *}$ \\
\hline Middle education & $0.006(0.003)^{* *}$ & $0.006(0.003)^{* *}$ & $0.007(0.003)^{* * *}$ & $0.007(0.003)^{* * *}$ \\
\hline Income & $0.021(0.005)^{* * *}$ & $0.021(0.005)^{* * *}$ & $0.021(0.005)^{* * *}$ & $0.021(0.005)^{* * *}$ \\
\hline Male & $0.011(0.002)^{* * *}$ & $0.011(0.002)^{* * *}$ & $0.011(0.002)^{* * *}$ & $0.011(0.002)^{* * *}$ \\
\hline
\end{tabular}


Table 2. Continued.

\begin{tabular}{|c|c|c|c|c|}
\hline & Model I & Model II & Model III & Model IV \\
\hline Intercept & $0.336(0.013)^{* * *}$ & $0.326(0.014)^{* * *}$ & $0.321(0.015)^{* * *}$ & $0.325(0.014)^{* * *}$ \\
\hline $\begin{array}{l}\text { Variance components } \\
\text { Country level constant } \\
\text { Individual level constant }\end{array}$ & $\begin{array}{l}0.063(0.008)^{* * *} \\
0.176(0.001)^{* * *}\end{array}$ & $\begin{array}{l}0.063(0.008)^{* * *} \\
0.176(0.001)^{* * *}\end{array}$ & $\begin{array}{l}0.063(0.008)^{* * *} \\
0.176(0.001)^{* * *}\end{array}$ & $\begin{array}{l}0.063(0.008)^{* * *} \\
0.176(0.001)^{* * *}\end{array}$ \\
\hline $\begin{array}{l}\mathrm{N}(\text { level 1) } \\
\mathrm{N}(\text { level 2) } \\
\text { Wald chi-sq. } \\
\text { Prob > chi-sq. } \\
-2 \mathrm{x} \text { LL }\end{array}$ & $\begin{array}{r}27398 \\
36 \\
1521.55 \\
0.000 \\
-17361.58\end{array}$ & $\begin{array}{r}27398 \\
36 \\
1525.88 \\
0.000 \\
-17365.66\end{array}$ & $\begin{array}{r}27398 \\
36 \\
1525.91 \\
0.000 \\
-17365.69\end{array}$ & $\begin{array}{r}27398 \\
36 \\
1527.70 \\
0.000 \\
-17367.38\end{array}$ \\
\hline
\end{tabular}

Notes: Table entries are unstandardized coefficients with standard errors in parentheses. ${ }^{*} P<0.10,{ }^{* *} P<0.05,{ }^{* * *} P<0.01$. 
and attendance at religious services are positive, but, again, the interaction effects are negative and statistically significant - higher support for democracy bolsters the positive effect religiosity has on deterring corrupt behaviour. Once religious belief and religious social behaviour are taken into account, specific religious beliefs do not necessarily have a substantive effect on corrupt behaviour. We systematically find that Catholic and Orthodox identifications tend to increase justifiability of corruption, but, with the exception of these, the rest of the denominations do not have a statistically significant effect on support for corrupt behaviour.

\section{Discussion and conclusions}

For years, religion has been largely ignored in the study of politics. Yet, as political occurrences worldwide indicate, religion plays an important role in many aspects of social and political life. This article contributes to the extant literature by showing that religion can be a source of good governance. The presence of religious cues in state institutions systematically decreases levels of corruption. This effect, however, is conditional on the institutional framework in place. In a democratic context, corruption is viewed as unethical and inappropriate. The effect of freedom of religion, which is to increase the type of behaviour that is perceived as ethical, would in this context translate into a reduction in corrupt behaviour. Conversely, in a non-democratic context, behaving morally does not always mean staying away from corruption. Where political corruption is not viewed as an unethical behaviour, religious cues are unlikely to suppress it.

We tested the interactive effect of democratic institutions and religion on corruption with two independent sets of data at two levels of analysis, and found robust support. At the macro level, analysis of data from 129 nations over a period of 12 years indicates that the positive effect of religious freedom on limiting corruption is conditional on the level of democracy in a country. Further, our hypothesis rests on the notion that the positive effect of religion on reducing corruption depends on the extent to which the individual internalizes democratic values. Accordingly, we also conducted an individual-level analysis using data from the latest wave of the World Values Surveys. The results provide strong empirical support for our contention that, for religious cues to have a beneficial effect on non-corrupt behaviour, the public should be supportive of democratic norms promoting good governance.

This work makes several significant contributions to the literature. At the level of theory, we combine institutional and political-psychological approaches to study the antecedents of corruption. We posit that religious cues in the context of the political apparatus would affect decision-makers to act morally. Yet, acting morally would depend on the institutional context. In a democracy, being morally virtuous would mean avoiding corruption. At the empirical level, while important lessons about ways to limit corruption are gleaned from institutional analysis, this work sheds new light on the topic. We demonstrate empirically how the psychological effects of religion and the institutional environment interact to influence corruption. 
This work offers some important observations and empirical predictions to be further developed and tested in future work. The combination of insights from political-psychological scholarship on the one hand and institutional scholarship on the other provides a theoretical framework that is not only more nuanced, but also offers considerably more explanatory power. The psychological effects are contingent on the institutional context, and the institutional consequences are a function of certain mental processes. This would be a fertile theoretical framework not only for the study of religion and corruption, but also for the examination of a host of other political phenomena, traditionally studied discretely using either theories from the political-psychological realm or accounts from the world of political institutions.

Finally, the conclusions of the analyses presented here are pertinent to the work of scholars as well as to leaders - religious and otherwise. Religion is playing an increasingly larger role in politics worldwide; religious movements in the Middle East are gaining power, some of the political violence in Europe has religious overtones, and some of the key ongoing conflicts, both between nations and within them, are related to religion. Yet, as the findings of this study illustrate, some of the implications of religion within the political realm may in fact be positive. At least as far as corruption is concerned, the effects of religion on politics are conditional on the institutional framework in place. Religion as such does not have the power to purge the political system of corruption. Yet, with the appropriate institutional platform, religion may be instrumental in the eradication of corruption.

\section{Notes}

1. Peters and Welch, 'Political Corruption in America'.

2. Nas, Price, and Webber, 'A Policy-oriented Theory of Corruption'; Meier and Holbrook, "I Seen My Opportunities and I Took 'Em": Political Corruption in the American States'; Lederman, Loayza, and Soares, 'Accountability and Corruption: Political Institutions Matter'; Alt and Lassen, 'The Political Economy of Institutions and Corruption in American States'; Kunicova and Rose-Ackerman, 'Electoral Rules as Constraints on Corruption'.

3. Powell and Whitten, 'A Cross-national Analysis of Economic Voting'; Tavits, 'Clarity of Responsibility and Corruption'.

4. Golden, 'Electoral Connections'.

5. Heilbrunn, 'Oil and Water? Elite Politicians and Corruption in France'; Tavits, 'Clarity of Responsibility and Corruption'.

6. Persson, Tabellini, and Trebbi, 'Electoral Rules and Corruption'.

7. Chang, 'Electoral Incentives for Political Corruption under Open-List Proportional Representation'.

8. Gerring and Thacker, 'Political Institutions and Corruption'.

9. Chang and Golden, 'Electoral Systems, District Magnitude and Corruption'.

10. Cox and Kousser, 'Turnout and Rural Corruption'.

11. Davis, Camp, and Coleman, 'The Influence of Party Systems on Citizens' Perceptions of Corruption and Electoral Response in Latin America'.

12. Gillespie and Okruhlik, 'The Political Dimension of Corruption Cleanups'.

13. For instance, economic structure and population density (Banerjee, 'A Theory of Misgovernance'; Herbst, States and Power in Africa), colonial legacy (Treisman, 'The 
Causes of Corruption'), the independence of the media (Peters and Welch, 'The Effects of Charges of Corruption on Voting Behavior in Congressional Elections'; Giglioli, 'Political Corruption and the Media') and levels of globalization and international integration (Sandholtz and Gray, 'International Integration and National Corruption'; Sandholtz and Koetzle, 'Accounting for Corruption') have also been noted as influencing such violation of norms of public service.

14. Uslaner, Corruption, Inequality, and the Rule of Law.

15. Basabe and Ros, 'Cultural Dimensions and Social Behavior Correlates'.

16. Licht, Goldschmidt, and Schwartz, 'Culture Rules', 665.

17. La Porta et al., 'Trust in Large Organizations'; Putnam, Making Democracy Work; Uslaner, 'Trust and Corruption'.

18. Putnam, Making Democracy Work; Treisman, 'The Causes of Corruption'; Landes, The Wealth and Poverty of Nations; La Porta et al., 'The Quality of Government'; Lipset and Lenz, 'Corruption, Culture and Markets'; Paldam, 'Corruption and Religion'; Basabe and Ros, 'Cultural Dimensions and Social Behavior Correlates'; Licht, Goldschmidt, and Schwartz, 'Culture Rules'.

19. For example, Licht, Goldschmidt, and Schwartz, 'Culture Rules'.

20. Basabe and Ros, 'Cultural Dimensions and Social Behavior Correlates'.

21. Putnam, Making Democracy Work.

22. Landes, The Wealth and Poverty of Nations.

23. Putnam, Making Democracy Work, 107.

24. Landes, The Wealth and Poverty of Nations.

25. Banfield, The Moral Basis of a Backward Society; Wraith and Simkins, Corruption in Developing Countries; Heidenheimer, Political Corruption.

26. Torgler, 'The Importance of Faith: Tax Morale and Religiosity'.

27. For example, Hoge and Yang, 'Determinants of Religious Giving in American Denominations'; Forbes and Zampelli, 'Religious Giving by Individuals'; Brooks, 'Religious Faith and Charitable Giving'; Chang, 'Religious Giving, Non-religious Giving, and After-life Consumption'.

28. Mazar, Amir, and Ariely, 'The Dishonesty of Honest People'.

29. Fishbach, Friedman, and Kruglanski, 'Leading Us Not Unto Temptation'; RandolphSeng and Nielsen, 'Honesty: One Effect of Primed Religious Representation'.

30. McKay et al., 'Wrath of God'.

31. Shariff and Norenzayan, 'God is Watching You'; Pichon, Boccato, and Saroglou, 'Nonconscious Influences of Religion on Prosociality'.

32. Randolph-Seng and Nielson, 'Honesty: One Effect of Primed Religious Representation'.

33. Mazar, Amir, and Ariely, 'The Dishonesty of Honest People'.

34. Shariff and Norenzayan, 'God is Watching You'.

35. Randolph-Seng and Nielsen, 'Honesty: One Effect of Primed Religious Representation'.

36. Mazar, Amir, and Ariely, 'The Dishonesty of Honest People'.

37. Adorno et al., The Authoritarian Personality; Gibson, 'The Political Consequences of Intolerance'; Hunsberger, 'Religion and Prejudice'; Karpov, 'Religiosity and Tolerance in the United States and Poland'. These effects are a result of religion's ability to enhance commitment to coalitional identities and strongly differentiate between in- and out-group interests (Atran, 'Genesis of Suicide Terrorism'; Irons, 'Religion as a Hard-To-Fake Sign of Commitment'; Choi and Bowles, 'The Coevolution of Parochial Altruism and War').

38. Grim and Finke, The Price of Freedom Denied.

39. Fox, A World Survey of Religion and the State; Fox, 'State Religious Exclusivity and Human Rights'. 
40. Johnson, Rowatt, and LaBouff, 'Priming Christian Religious Concepts Increases Racial Prejudice'.

41. Ginges, Hansen, and Norenzayan, 'Religion and Support for Suicide Attacks'.

42. Thus, religiosity may enhance altruistic or morally oriented behaviour that may be viewed normatively as negative by an outsider, such as in-group favouritism and out-group prejudice (on parochial altruism see Choi and Bowles, 'The Coevolution of Parochial Altruism and War'). A typical example that the effect of religion depends on what is viewed as moral in some context is the case of suicide bombing. Such behaviour can be seen as altruistic in some political and social context, and categorically immoral in some other context (see Ginges, Hansen, and Norenzayan, 'Religion and Support for Suicide Attacks', for the positive relationship between religious primes and approval of suicide attacks).

43. Inglehart, 'Post-Materialism in an Environment of Insecurity'; Abramson and Inglehart, Value Change in Global Perspective.

44. Bentham, 'Essay on Political Tactics'; Mill, Considerations on Representative Government.

45. It has been suggested that the British passed on the powerful norm of compliance with established procedures as opposed to personal authority (Treisman, 'The Causes of Corruption'). As a result, this better civil service code is expected to be associated with lower levels of corruption (although this expectation was challenged by some scholars, see for example Pellegrini and Gerlagh, 'Causes of Corruption'), while no similar theory applies to other former colonies. We thus control solely for being a former British colony. In fact, addition of a French colony dummy does not lead to any substantive change in results, and shows a statistically insiginficant coefficient.

46. See details on methods used in data collection and use in academic work on the PRS website at http://www.prsgroup.com. Data were purchased on the website in January 2011.

47. Thompson and Shah, 'Transparency International's Corruption Perceptions Index'.

48. Data were taken from the RAS website in October 2010 - http://www.thearda.com/ ras/.

49. For a more detailed review of the measures, see Fox, $A$ World Survey of Religion and the State, chapter 3.

50. See Hadenius and Teorell, 'Cultural and Economic Prerequisites of Democracy', for the advantages of this measure.

51. Dreher, 'Does Globalization Affect Growth?'; Dreher et al., Measuring Globalization.

52. Gleditsch, 'Expanded Trade and GDP Data'.

53. Zorn, 'Generalized Estimating Equation Models for Correlated Data'.

54. Ibid., 475.

55. Treisman, 'The Causes of Corruption'.

56. See, for example, Pellegrini and Gerlagh, 'Causes of Corruption'.

57. See Steenbergen and Jones, 'Modeling Multilevel Data Structures'.

58. The classification of religious denominations used in the analysis is based on BenNun Bloom and Arikan, 'A Two-edged Sword'.

\section{Notes on contributors}

Udi Sommer is assistant professor at the political science department at Tel Aviv University. He specializes in the analysis of political institutions. Sommer's scholarship has appeared or is forthcoming in publications such as Comparative Political Studies, Rationality and Society, Judicature and Justice System Journal. Sommer is a recipient of the Marie Curie Grant, the Fulbright Doctoral Fellowship and a grant from the American National Science Foundation. 
Pazit Ben-Nun Bloom is Assistant Professor in the Department of Political Science at the Hebrew University of Jerusalem, Israel. Her research examines the role of morality, religiosity and values in political behaviour.

Gizem Arikan is Assistant Professor in the Department of International Relations at Yasar University, Izmir, Turkey. Her research focuses on the effect of political culture and values on public opinion and policy. She also conducts research on religiosity and attitudes towards democracy.

\section{Bibliography}

Abramson, P.R., and R. Inglehart. Value Change in Global Perspective. Ann Arbor, MI: University of Michigan Press, 1995.

Adorno, T.W., E. Frenkel-Brunswik, D.J. Levinson, and R.N. Sanford. The Authoritarian Personality. New York: Harper and Row, 1950.

Alt, J.E., and D.D. Lassen. 'The Political Economy of Institutions and Corruption in American States'. Journal of Theoretical Politics 15, no. 3 (2003): 341-65.

Atran, S. 'Genesis of Suicide Terrorism'. Science 299 (2003): 1534-9.

Banerjee, A. 'A Theory of Misgovernance'. Quarterly Journal of Economics 112 (1997): $1289-332$.

Banfield, E.C. The Moral Basis of a Backward Society. New York: Free Press, 1958.

Basabe, N., and M. Ros. 'Cultural Dimensions and Social Behavior Correlates: Individualism-Collectivism and Power Distance'. Revue Internationale de Psychologie Sociale 1, no. 1 (2005): 189-225.

Ben-Nun Bloom, P., and G. Arikan. 'A Two-edged Sword: The Differential Effect of Religious Belief and Religious Social Context on Attitudes towards Democracy'. Political Behavior (forthcoming 2012).

Bentham, J. 'Essay on Political Tactics'. In The Works of Jeremy Bentham, ed. John Browning, 310-17. Edinburgh: William Tait, 1839.

Brooks A.C. 'Religious Faith and Charitable Giving'. Policy Review 121 (2003): 39-48.

Chang, E.C.C. 'Electoral Incentives for Political Corruption under Open-List Proportional Representation'. The Journal of Politics 67, no. 3 (2005): 716-30.

Chang, E.C.C., and M.A. Golden. 'Electoral Systems, District Magnitude and Corruption'. British Journal of Political Science 37, no. 1 (2007): 115-37.

Chang W.C. 'Religious Giving, Non-religious Giving, and After-life Consumption'. Topics in Economic Analysis and Policy 5, no. 1 (2005): 13.

Choi, J., and S. Bowles. 'The Coevolution of Parochial Altruism and War'. Science 318 (2007): 636-40.

Cox, G.W., and J.M. Kousser. 'Turnout and Rural Corruption: New York as a Test Case'. American Journal of Political Science 25, no. 4 (1981): 646-63.

Davis, C.L., R. Ai Camp, and K.M. Coleman. 'The Influence of Party Systems on Citizens' Perceptions of Corruption and Electoral Response in Latin America'. Comparative Political Studies 37, no. 6 (2004): 677-703.

Dreher, A. 'Does Globalization Affect Growth? Evidence from a New Index of Globalization'. Applied Economics 38, no. 10 (2006): 1091-110.

Dreher, A., N. Gaston, P. Martens, and W.J.M. Martens. Measuring Globalization: Gauging its Consequences. New York: Springer, 2008.

Fishbach, A., R.S. Friedman, and A.W. Kruglanski. 'Leading Us Not Unto Temptation: Momentary Allurements Elicit Overriding Goal Activation'. Journal of Personality and Social Psychology 84 (2003): 296-309.

Forbes, K.F., and E.M. Zampelli. 'Religious Giving by Individuals: A Cross Denominational Study'. The American Journal of Economics and Sociology 56, no. 1 (1997): $17-30$. 
Fox, J. A World Survey of Religion and the State. Cambridge: Cambridge University Press, 2008.

Fox, J. 'State Religious Exclusivity and Human Rights'. Political Studies 56, no. 4 (2008): $928-48$.

Gerring, J., and S.C. Thacker. 'Political Institutions and Corruption: The Role of Unitarism and Parliamentarism'. British Journal of Political Science 34, no. 2 (2004): 295-330.

Gibson J.L. 'The Political Consequences of Intolerance: Cultural Conformity and Political Freedom'. American Political Science Review 86 (1992): 338-56.

Giglioli, P.P. 'Political Corruption and the Media: The Tangentopoli Affair'. International Social Science Journal 48 (1996): 381-94.

Gillespie K., and G. Okruhlik. 'The Political Dimension of Corruption Cleanups: A Framework for Analysis'. Comparative Politics 24 (1991): 77-95.

Ginges, J., I. Hansen, and A. Norenzayan. 'Religion and Support for Suicide Attacks'. Psychological Science 20 (2009): 224-30.

Gleditsch, K.S. 'Expanded Trade and GDP Data'. Journal of Conflict Resolution 46 (2002): $712-24$.

Golden, M.A. 'Electoral Connections: The Effects of the Personal Vote on Political Patronage, Bureaucracy and Legislation in Postwar Italy'. British Journal of Political Science 33, no. 2 (2003): 189-212.

Grim, Brian J., and Roger Finke. The Price of Freedom Denied: Religious Persecution and Conflict in the Twenty-First Century. Cambridge: Cambridge University Press, 2011.

Hadenius A., and Jan Teorell. 'Cultural and Economic Prerequisites of Democracy: Reassessing Recent Evidence'. Studies in Comparative International Development 39 (2005): $87-106$.

Heidenheimer, A.J. Political Corruption: Readings in Comparative Analysis. New Brunswick, NJ: Transaction Books, 1970.

Heilbrunn, J.R. 'Oil and Water? Elite Politicians and Corruption in France'. Comparative Politics 37, no. 3 (2005): 277-96.

Herbst, J. States and Power in Africa: Comparative Lessons in Authority and Control. Princeton, NJ: Princeton University Press, 2000.

Hoge, D.R., and F. Yang. 'Determinants of Religious Giving in American Denominations: Data from Two Nationwide Surveys'. Review of Religious Research 36 (1994): 123 48.

Hunsberger, Bruce. 'Religion and Prejudice: The Role of Religious Fundamentalism, Quest, and Right-wing Authoritarianism'. Journal of Social Issues 51 (1995): 113-29.

Inglehart, R. 'Post-Materialism in an Environment of Insecurity'. The American Political Science Review 75, no. 4 (1981): 880-990.

Irons, W. 'Religion as a Hard-To-Fake Sign of Commitment'. In Evolution and the Capacity for Commitment, ed. R. Nesse, 292-309. New York: Russell Sage Foundation, 2001.

Johnson, M.K., W.C. Rowatt, and J. LaBouff. 'Priming Christian Religious Concepts Increases Racial Prejudice'. Social Psychological and Personality Science 1, no. 2 (2010): 119-26.

Karpov, V. 'Religiosity and Tolerance in the United States and Poland'. Journal for the Scientific Study of Religion 41, no. 2 (2002): 267-88.

Kunicova, J., and S. Rose-Ackerman. 'Electoral Rules as Constraints on Corruption'. British Journal of Political Science 35, no. 4 (2005): 573-606.

La Porta, R., F. Lopez-de-Silanes, A. Shleifer, and R.W. Vishnv. 'The Quality of Government'. Journal of Law, Economics and Organization 15, no. 1 (1999): 222-79.

La Porta, R., F. Lopez-De-Silanes, A. Shleifer, and R.W. Vishny. 'Trust in Large Organizations'. American Economic Review Papers and Proceedings 87 (1997): 333-8.

Landes, D. The Wealth and Poverty of Nations. New York: W.W. Norton, 1998. 
Lederman, D, M. Loayza, and R. Soares. 'Accountability and Corruption: Political Institutions Matter'. World Bank Working Paper No. 2708. Washington DC: World Bank, 2001.

Licht, A., C. Goldschmidt, and S. Schwartz. 'Culture Rules: The Foundations of the Rule of Law and Other Norms of Governance'. Journal of Comparative Economics 35 (2007): $659-88$.

Lipset, S.M., and G.S. Lenz. 'Corruption, Culture and Markets'. In Culture Matters: How Values Shape Human Progress, ed. L.E. Harrison and S.P. Huntington, 112-24. New York: Basic Books, 2000.

Mazar, N., O. Amir, and D. Ariely. 'The Dishonesty of Honest People: A Theory of SelfConcept Maintenance'. Journal of Marketing Research 45, no. 6 (2008): 633-44.

McKay, R., C. Efferson, H. Whitehouse, and E. Fehr. 'Wrath of God: Religious Primes and Punishment'. Proceedings of the Royal Society Series B - Biological Sciences 278, no. 1713 (2011): 1858-63.

Meier, K.J., and T.M. Holbrook. "II Seen My Opportunities and I Took 'Em”: Political Corruption in the American States'. The Journal of Politics 54, no. 1 (1992): 135-55.

Mill, J.S. Considerations on Representative Government. South Bend: Gateway, 1962.

Nas, T.F., A.C. Price, and C.S. Weber. 'A Policy-oriented Theory of Corruption'. The American Political Science Review 80, no. 1 (1986): 107-19.

Paldam, M. 'Corruption and Religion: Adding to the Economic Model'. Kyklos 54, nos 2-3 (2001): 383-413.

Pellegrini, R., and R. Gerlagh. 'Causes of Corruption: A Survey of Cross-country Analyses and Extended Results'. Economics of Governance 9 (2008): 245-63.

Persson, T., G. Tabellini, and F. Trebbi. 'Electoral Rules and Corruption'. NBER Working Paper No. 8154. Cambridge, MA: NBER, 2001.

Peters, J.G., and S. Welch. 'The Effects of Charges of Corruption on Voting Behavior in Congressional Elections'. The American Political Science Review 74, no. 3 (1980): 697-708.

Peters, J.G., and S. Welch. 'Political Corruption in America: A Search for Definitions and a Theory or If Political Corruption is in the Mainstream of American Politics Why is it not in the Mainstream of American Politics Research?'. The American Political Science Review 72, no. 3 (1978): 974-84.

Pichon, I., G. Boccato, and V. Saroglou. 'Nonconscious Influences of Religion on Prosociality: A Priming Study'. European Journal of Social Psychology 37, no. 5 (2007): 1032-45.

Powell, B.G., and G.D. Whitten. 'A Cross-national Analysis of Economic Voting: Taking Account of the Political Context'. American Journal of Political Science 37, no. 2 (1993): 391-414.

Putnam, R. Making Democracy Work: Civic Traditions in Modern Italy. Princeton, NJ: Princeton University Press, 1993.

Randolph-Seng, B., and M.E. Nielsen. 'Honesty: One Effect of Primed Religious Representation'. International Journal for the Psychology of Religion 17 (2007): 303-15.

Sandholtz, W., and M. Gray. 'International Integration and National Corruption'. International Organization 57, no. 4 (2003): 761-800.

Sandholtz, W., and W. Koetzle. 'Accounting for Corruption: Economic Structure, Democracy, and Trade'. International Studies Quarterly 44, no. 1 (2000): 31-50.

Shariff, A.F., and A. Norenzayan. 'God is Watching You: Supernatural Agent Concepts Increase Prosocial Behavior in an Anonymous Economic Game'. Psychological Science 18 (2007): 803-9.

Steenbergen, M., and B. Jones. 'Modeling Multilevel Data Structures'. American Journal of Political Science 46, no. 1 (2002): 218-37. 
Tavits, M. 'Clarity of Responsibility and Corruption'. American Journal of Political Science 51, no. 1 (2007): 218-29.

Thompson, T., and A. Shah. 'Transparency International's Corruption Perceptions Index: Whose Perceptions Are They Anyway?', 2005, http://siteresources.worldbank.org/ PSGLP/Resources/ShahThompsonTransparencyinternationalCPI.pdf (accessed March 1, 2011).

Torgler, B. 'The Importance of Faith: Tax Morale and Religiosity'. Journal of Economic Behavior and Organization 61 (2006): 81-109.

Treisman, D.S. 'The Causes of Corruption: A Cross-national Study'. Journal of Public Economics 76 (2000): 399-457.

Uslaner, E. Corruption, Inequality, and the Rule of Law: The Bulging Pocket Makes the Easy Life. New York: Cambridge University Press, 2008.

Uslaner, E. 'Trust and Corruption'. In The New Institutional Economics of Corruption Norms, Trust, and Reciprocity, ed. J.G. Lambsdorff, M. Schramm, and M. Taube, 76-92. London: Routledge, 2004.

Wraith, R.E., and E. Simkins. Corruption in Developing Countries. London: Allen and Unwin, 1963.

Zorn, C.J.W. 'Generalized Estimating Equation Models for Correlated Data: A Review With Applications'. American Journal of Political Science 45, no. 2 (2001): 479-90. 


\section{Appendix}

Table A1. Simple effects of the interactions in Figures 1 and 2.

\begin{tabular}{|c|c|c|c|c|c|c|c|c|}
\hline & & \multirow[b]{2}{*}{ Coefficient } & \multirow[b]{2}{*}{ Std. error } & \multirow[b]{2}{*}{$\mathrm{Z}$} & \multicolumn{2}{|c|}{ CI 95\% } & \multicolumn{2}{|c|}{ CI $90 \%$} \\
\hline & & & & & Lower & Upper & Lower & Upper \\
\hline \multirow[t]{6}{*}{ Regulation } & Democratization low & -0.229 & 0.220 & -1.04 & -0.660 & 0.203 & -0.591 & 0.133 \\
\hline & Democratization medium & 0.334 & 0.299 & 1.12 & -0.251 & 0.920 & -0.157 & 0.826 \\
\hline & Democratization high & 1.060 & 0.530 & 2.00 & 0.022 & 2.098 & 0.189 & 1.931 \\
\hline & GDP low & -0.301 & 0.161 & -1.87 & -0.617 & 0.014 & -0.566 & -0.036 \\
\hline & GDP medium & 0.154 & 0.241 & 0.64 & -0.317 & 0.626 & -0.241 & 0.550 \\
\hline & GDP high & 0.948 & 0.504 & 1.88 & -0.040 & 1.937 & 0.119 & 1.778 \\
\hline \multirow[t]{3}{*}{ Discrimination } & GDP low & 0.186 & 0.363 & 0.51 & -0.527 & 0.898 & -0.412 & 0.783 \\
\hline & GDP medium & 0.027 & 0.190 & 0.14 & -0.346 & 0.399 & -0.286 & 0.339 \\
\hline & GDP high & 1.002 & 0.379 & 2.64 & 0.259 & 1.744 & 0.379 & 1.625 \\
\hline
\end{tabular}

Notes: Table entries are coefficients, standard errors, $Z$ value and confidence intervals for the effect of regulation/discrimination when democratization/GDP is at the lowest $20 \%$, between $40-60 \%$, and highest $20 \%$. 